\title{
Part-time work and childbirth in Europe: Scarring the career or meeting working-time preferences?
}

Citation for published version (APA):

Fouarge, D., \& Muffels, R. (2008). Part-time work and childbirth in Europe: Scarring the career or meeting working-time preferences? In R. Muffels (Ed.), Flexibility And Employment Security In Europe. Labour Markets in Transition (pp. 223-254). Edward Elgar Publishing. https://doi.org/10.4337/9781781007693.00016

Document status and date:

Published: 01/01/2008

DOI:

10.4337/9781781007693.00016

Document Version:

Publisher's PDF, also known as Version of record

\section{Please check the document version of this publication:}

- A submitted manuscript is the version of the article upon submission and before peer-review. There can be important differences between the submitted version and the official published version of record.

People interested in the research are advised to contact the author for the final version of the publication, or visit the DOI to the publisher's website.

- The final author version and the galley proof are versions of the publication after peer review.

- The final published version features the final layout of the paper including the volume, issue and page numbers.

Link to publication

\footnotetext{
General rights rights.

- You may freely distribute the URL identifying the publication in the public portal. please follow below link for the End User Agreement:

www.umlib.nl/taverne-license

Take down policy

If you believe that this document breaches copyright please contact us at:

repository@maastrichtuniversity.nl

providing details and we will investigate your claim.
}

Copyright and moral rights for the publications made accessible in the public portal are retained by the authors and/or other copyright owners and it is a condition of accessing publications that users recognise and abide by the legal requirements associated with these

- Users may download and print one copy of any publication from the public portal for the purpose of private study or research.

- You may not further distribute the material or use it for any profit-making activity or commercial gain

If the publication is distributed under the terms of Article $25 \mathrm{fa}$ of the Dutch Copyright Act, indicated by the "Taverne" license above, 


\section{Part-time Work and Childbirth in Europe: Scarring the Career or Meeting Working-time Preferences?}

\section{Didier Fouarge and Ruud Muffels}

\subsection{INTRODUCTION}

One major aspect of the transitionall labour market approach is its interest for the consequences of the ongoing individualisation process on the way people behave on the labour market. One important consequence of that is that women seek to develop their own career and tend to work more hours than they used to in the past. A second consequence is that due to women's increasing participation they desire more options to be able to combine working and caring duties. In general it seems that people want more leeway to adapt their labour supply to changing conditions over the life cycle and to improve their work-life balance. The TLM approach devotes particular interest into the role of life events such as childbirth, on the way people behave on the labour market and how they seek to improwe their work-life balance. In this chapter we focus on the effect of people's decisions in choosing particular combinations of working time and caring duties on the future career. We use the European Community Household Panel but added the Hungarian household panel to analyse the short and medium-term effects of the various types of combinations of part-time work and care breaks on the occupational career'. The Hungarian panel has been added to include at least one of the transition countries from the East. Transition countries are particularly interesting to study because part-time labour is a rather new phenomenon in these post-socialist countries. In particular, we try to assess the effect of part-time employment on the probability of being employed fulltime later in their career. Finally, we specifically assess the effect of a major life event - childbirth - on the future labour market participation and income position of females. Regression models on the changes in working time owing to the career break are used to examine the future income and 
employment effects across countries. The major question deals with the contended negative or "scarring" effect of part-time work on the future employment and wage career (see in particular Chapter 7).

The chapter is structured as follows. In Section 9.2, we discuss the background of the research and our research questions. Section 9.3 discusses the data used and the selection of the main dependent variables. Descriptive results for part-time employment, transitions from part-time work and motives for working part-time are reported in Section 9.4 and model estimates in Section 9.5. Section 9.6 reports on the effect of childbirth on the labour market participation of young women, both in terms of the participation decision and the number of hours worked, while the effect of childbirth on labour market income is studied in Section 9.7. The main findings are summarised in Section 9.8 .

\subsection{BACKGROUND AND RESEARCH QUESTION}

\subsubsection{Previous Research}

The incidence of part-time employment varies considerably for male and female workers as well as across countries of the EU. According to data from the Labour Force Survey, in 2005, 7.5 per cent of European male workers were employed in a part-time job, but this percentage varied from as low as 1.3 per cent in Slovakia to as much as 22.6 per cent in the Netherlands. For females the rates of part-time employment were higher. More than a third of employed women are working in a part-time job. Again, that percentage is lowest in Slovakia (4.1 per cent) but largest in the Netherlands ( 75 per cent). These numbers suggest that across Europe, people chose different combinations of working time and caring duties. These choices turn out to be very different both across gender and across countries.

In the literature, much attention has already been devoted to part-time employment and its consequences for participation later in the working life, but also on its consequence for future income. Although some authors have suggested that part-time jobs could be a springboard towards full-time jobs (Blank, 1989), there is little evidence that this is indeed the case in Europe. Recent studies for European countries have shown that most females who do work part-time are not so likely to move into a full-time job (O'Reilly and Bothfeld, 2002; Buddelmeyer et al., 2005). Furthermore, a Dutch study shows that also in the 'first part-time economy of the world' employees still experience a lower wage and social status as a consequence of part-time employment even several years after they have returned into a full-time job (Román, Fouarge and Luijkx, 2004). 
Childbirth has also been shown to affect the participation decision of working mothers. Due the increased time squeeze after childbirth, mothers have a higher tendency than fathers to withdraw from the labour force (Dekker et al., 2000). Several studies, however, have illustrated the importance of institutional arrangements in keeping mothers in paid employment. In countries where the supply of female-friendly institutions (for example childcare) is higher, females have a higher probability of remaining in paid employment (Kenjoh, 2003; Gornick et al., 1998; Uunk et al., 2005). Furthermore, in such countries women seem more likely to work more hours (Van der Lippe, 2001).

\subsubsection{Research Question and Expectations}

Here we deal with four main research questions. They pertain to the effect of caring and part-time employment on future employment opportunities and to the effects of childbirth on the employment and wage career. With respect to the latter, we firstly investigate to what extent part-time employment has a 'scar effect' on employment later in the career, that is, we investigate to what extent part-timers workers have lower opportunities to move on to full-time jobs, conditional on their preferences and their life cycle phase. Secondly, we investigate the effect of childbirth on the decision to withdraw or to stay in the labour market and to choose for a certain number of weekly working hours. By doing so, we are able to compare the number of hours worked preand post childbirth. Thirdly, we examine the income consequences of childbirth.

From the existing literature on the subject we have derived some expectations about the effects we are likely to find:

1. Following the 'scarring' theory we assume that to the extent that working part-time has an adverse or 'scarring' effect on employment opportunities later in working life, part-time workers are expected to have a lower probability to be employed full-time later in the career than full-time workers.

2. Following human capital theory (Becker, 1964), we assume that parttimers build up less human capital during their part-time career and therefore are more likely to make a transition into non-employment.

3. For the same reason we contend that part-time employment reduces the probability of subsequent full-time employment, though we also presume that the longer people work part-time the more human capital has been built up and the smaller these effects tend to be as time passes.

4. If neo-classical economic theory has a bearing for women's labour supply decisions (Becker, 1981), we might assume that the price of leisure is lower due to the costs involved in caring because of which women choose to work part-time. In that case part-time work is associat- 
ted with personal preferences for working fewer hours due to caring and not a "scarring" phenomenon for which reason we might predict that the transition into full-time employment is less likely to occur.

5. Also according to neo-classical thinking, if the costs of caring are high, for example, due to the lack of sufficient income support through public policies, childbirth is expected to result in a reduction of labour market income caused by the reduction in participation - which is then only partly compensated by the public income transfers (mainly child benefits), see Uunk et al. (2005).

\subsection{DATA AND MAIN DEFINITIONS}

\subsubsection{Panel Data}

For this chapter, we have used the data from the European Cornmunity Household Panel (ECHP), supplemented with the panel data for Hungary to acquire some idea on how dissimilar the results are for different parts of Europe with a different background and tradition in part-time work. The ECHP contains panel data (repeated measurement among the same sample of people) for $14 \mathrm{EU}$ countries. For the UK, Germany and Luxembourg the ECHP contains two sources of information: ECHP-specific panel data, and panel data from the three national panels. ${ }^{2}$ For these countries, we use the latter source. For all but three countries, data are available for the years 1994-2001. For Austria and Luxembourg we have data from 1995, and for Finland the data start in 1996.

Hungarian panel data have been matched to the ECHP in a way that comparability of the variables used is ensured. The Hungarian data come from the CHER database (Consortium of Household Panels for European Socio-Economic Research), and were directly derived from the Hungarian Household Survey (HHS), Data are available for the years 1992-1997.

The data is organised as a pooled person-year file, with one record for each person at each point of interview. For the analysis, we retained only people of working age (18-64). For the analysis of the effect of childbirth on labour market participation, however, we focus on the age group 18-45. Our dataset includes some 100,000 respondents aged 18 to 64 per wave across 15 countries. It includes 60,000 to 76,000 people aged up to 45 years old per wave.

\subsubsection{Main Variables}

\section{Labour market status}

The number of hours worked per week (in the main and additional jobs) is reported in the datasets used. This will be the main variable on which we 
define labour market participation. In the analyses, we make a distinction between non-participation, part-time employment, and full-time employment. Non-participants are people working zero hours. It includes the unemployed, the disabled, as well as respondents who are currently not looking for a job. Small part-time jobs are defined as jobs of 1 to 14 hours per week. ${ }^{3}$ Part-time workers are respondents who are working 15-34 hours per week. Full-time workers are people working at least 35 hours per week. The variable is described in Table 9.1 .

Table 9.1 Labour market status according to the number of hours worked in pooled data file, (absolute numbers and percentages)

\begin{tabular}{lrc}
\hline & \multicolumn{1}{c}{$\mathrm{N}$} & $\%$ \\
\hline Does not work & 314,946 & 38.3 \\
$1-14$ hours & 19,685 & 2.4 \\
$15-34$ hours & 75,820 & 9.2 \\
$35+$ hours & 412,661 & 50.1 \\
\hline Total & 823,112 & 100 \\
\hline
\end{tabular}

Source: ECHP, 1994-2001 (Eurostat); HHS, 1992-1997 (TARKD).

\section{Income}

The effect of care on income is assessed by looking at the respondents" wage and non-wage income before and after childbirth. All incomes are expressed in purchasing power parities (PPP) as calculated by Eurostat in constant 2000 prices in order to ensure cross-country comparison. Total personal income refers to the annual net income from employment, private and public transfers. Wage income refers to the total net income from employment, while public transfers are the sum of all transfers paid to the individual such as unemployment and disability benefits, pensions, child or family allowances and so on. All incomes are measured in the year prior to the interview date. Except for France, all amounts are net of taxes and social security contributions. The hourly wage is measured by dividing the previous year's income by 52 , and then by the number of hours worked per week the previous year (at the time of last year's interview).

\section{Life course phase}

Over time people experience a number of demographic transitions:; for example leaving home, getting married, having children, getting divorced or separated and so on. To account for these different phases of the life course, we define a life course phase variable that accounts for the household structure, the presence of children, and the age of the youngest child. The variable is self-explanatory and is described in Table 9.2 . 


\section{Childbirth}

We construct a dummy variable for childbirth by comparing the number of children across waves. We define childbirth as the event that a new child enters the household, that is, when the number of children younger than 16 in wave $t$ is Jarger than in wave $t-1$.

Table 9.2 Life course phase, absolute number and the distribution of households in the pooled data file (absolute numbers and percentages)

\begin{tabular}{lcc}
\hline & $\mathrm{N}$ & $\%$ \\
\hline Couple no child & & $\%$ \\
Couple youngest child $0-5$ & 278,881 & 33.7 \\
Couple youngest child $6-16$ & 117,264 & 14.2 \\
Single no child* & 155,113 & 18.7 \\
Single youngest child $0-5$ & 218,335 & 26.4 \\
Single youngesi child $6-16$ & 10,914 & 1.3 \\
Total & 47,705 & 5.8 \\
\hline
\end{tabular}

Note: No child between the age of 0 and 16.

Sorrce: ECHP, 1994-200』 (Eurostaty; HHS, 1992-1997 (TARKI).

\subsection{DESCRIPTIVE RESULTS}

\subsubsection{Incidence of Part-time Employment}

The labour market status of males in the 15 countries included in our analysis is depicted in Figure 9.1. The data relate to the latest year available in the data: 1997 for Hungary and 2001 for all other countries. Figure 9.2 presents similar data for females. In both figures, the countries are sorted according to the inactivity rate.

Of all countries included, the labour force participation of males is lowest in Hungary and France. ${ }^{4}$ High employment rates ( 80 per cent or more) are found in Austria, the UK, Denmark, Luxembourg and the Netherlands. It is clear from this figure that part-time jobs are not popular among males, with the exception of the Netherlands perhaps where more than 10 per cent of males are employed for less than 35 hours a week. The picture for female labour participation in Europe is very diverse; more than half the females of working age are not employed in France, Hungary and the Southern countries Spain, Greece, and Italy. The large incidence of part-time employment in total employment, for example, in the Netherlands, is also reflected in Figure 9.2. The differences across countries, again, are substantial. 


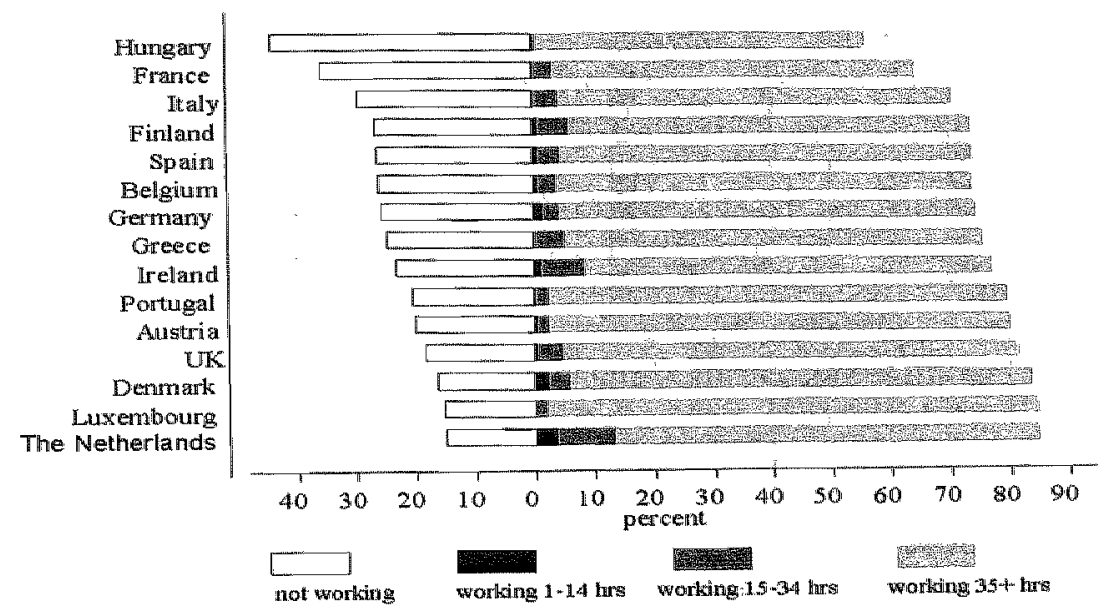

Note: 1997 data for Hungary.

Source: ECHP, 1994-2001 (Eurostat); HHS, 1992-1997 (TARKD).

Figure 9.1 Labour market participation of males (18-64), 2001 (\%) \% $^{\text {* }}$

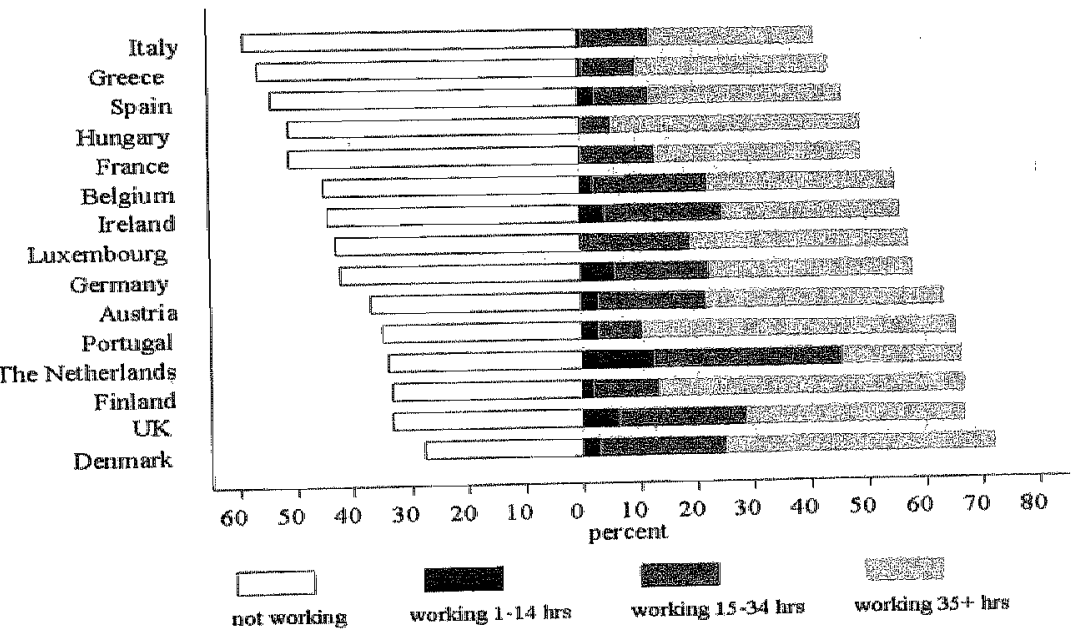

Note: 1997 data for Hungary.

Source: ECHP, 1994-2001 (Eurostat); HHS, 1992-1997 (TARKI).

Figure 9.2 Labour market participation of females (18-64), $2001(\%) *$ 
Although small part-time jobs remain a limited phenomenon even for females in most EU countries, a significant proportion of females in Ireland, the UK, Germany and especially the Netherlands do work in such jobs. With the exception of Greece, Portugal, Spain and Hungary, a significant percentage of females are employed in regular part-time jobs. In the Netherlands, a third of all working age females are working part-time. In Belgium, Denmark, Luxembourg, the UK and Ireland a fifth or more of all females is working part-time.

\subsubsection{Part-time and Caring Obligations}

There are basically two ways to assess the extent by which people who work part-time do so in order to be able to combine work with caring obligations and to improve their work-life balance: the so-called stated and revealed preferences method. With the "stated preferences approach", one relies on the subjective answers to a question pertaining to the reason why respondents are working in part-time jobs. With the 'revealed preferences approach' one would look at the coincidence or association between variables indicating whether people actually work part-time and objective indicators for being engaged in caring obligations. In this section. we use both methods in turn.

\section{Reason for working part-time}

In the ECHP questionnaire respondents were asked for the main reason why they work part-time. Respondents could choose among six reasons. The information, however, is missing for the UK and Luxembourg, and the question for Germany only allows for choosing between two reasons. Unfortunately, no such information is available in the Hungarian panel. Note that the definition of part-time work used in the ECHP is slightly different from the one used here: the question was asked to everyone working less than 30 hours.

The main reason why males work part-time in Denmark and the Netherlands but also in Finland, Belgium, Germany, Austria and Ireland is, as they report so, because they are undergoing education or training, (Figure 9.3).

In France, Greece, Spain, Italy, but also in Portugal and Be]gium, a significant percentage of males who are working part-time report do so because they are unable to find a full-time job. A part-time job seems to act as a second-best option due to the unavailability of a full-time job. In those countries. more than in others, males seem to be confronted with a constrained labour supply for they are unable to work the number of hours they prefer to work. With a view to these results, it must be concluded that caring obligations are not the main reason for males working part-time, not even in the Netherlands where only 10 per cent report this to be the main reason. 


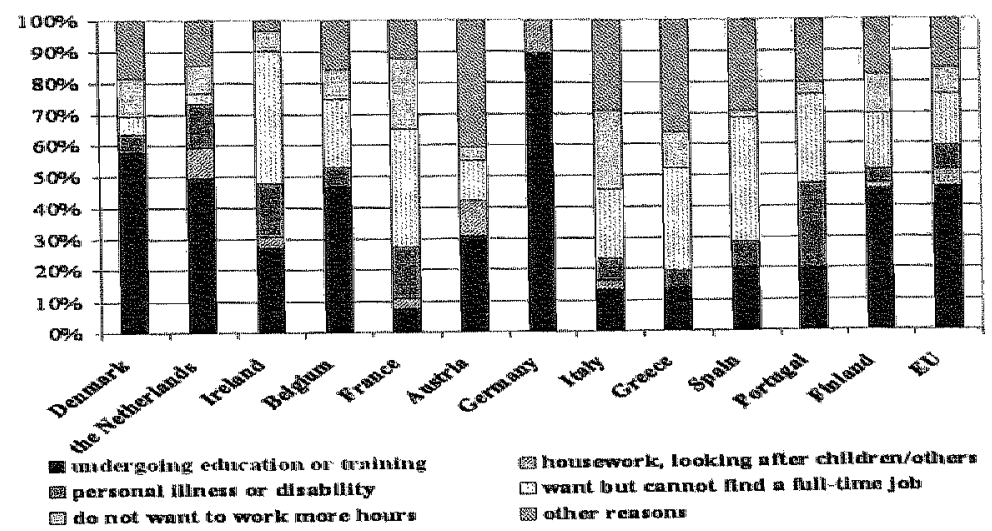

Source: ECHP, 1994-2001 (Eurostat).

Figure 9.3 Main reason for working part-time, males (18-64), 2001 (\%)

The picture for females looks rather different (Figure 9.4). In most EU countries, the main reason why females work part-time is because of household activities or caring obligations either for children or other dependents in the household. But it is worthwhile to note some country specific differences. In Denmark and Finland the main reason why females work part-time is because they undergo education or training. There, the picture is not very different from that of males.

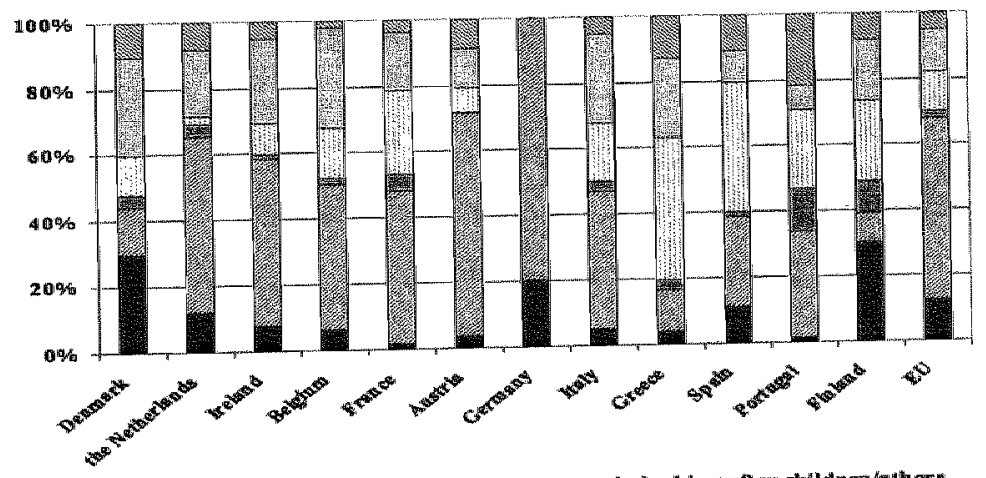

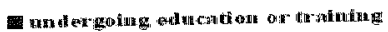

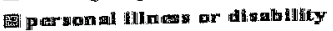

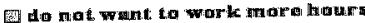

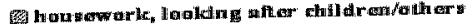

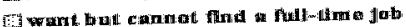

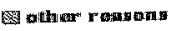

Sionre: ECHP, 1994-2001 (Eurostat).

Figure 9.4 Reason for working part-time, females (18-64), 2001 (\%) 
In most of the Southern European countries (Greece, Spain, but also Portugal), females - just like males - report they are constrained in their labour supply due to the unavailability of longer hours jobs. In France and Finland a fifth of the females working part-time also report they are unable to find a full-time job. When comparing Denmark and the Netherlands, it turns out that the share of femalles reporting housework as the main reason why they are working part-time is four times larger among Dutch females compared to Danish females.

\section{Part-time and life course phase}

In this part we discuss the relationship between labour market status and the life course stage of males and females. The labour market participation of males living in a couple appears to be larger than of single males (Figure 9.5). Associated with the presence of and care for children, they tend to participate more in the labour market. However, single males with caring obligations are, just as females, more likely to withdraw from the labour market and to become non-participants. Especially, when males living in a couple face the financial responsibilities of caring for children they tend to participate.

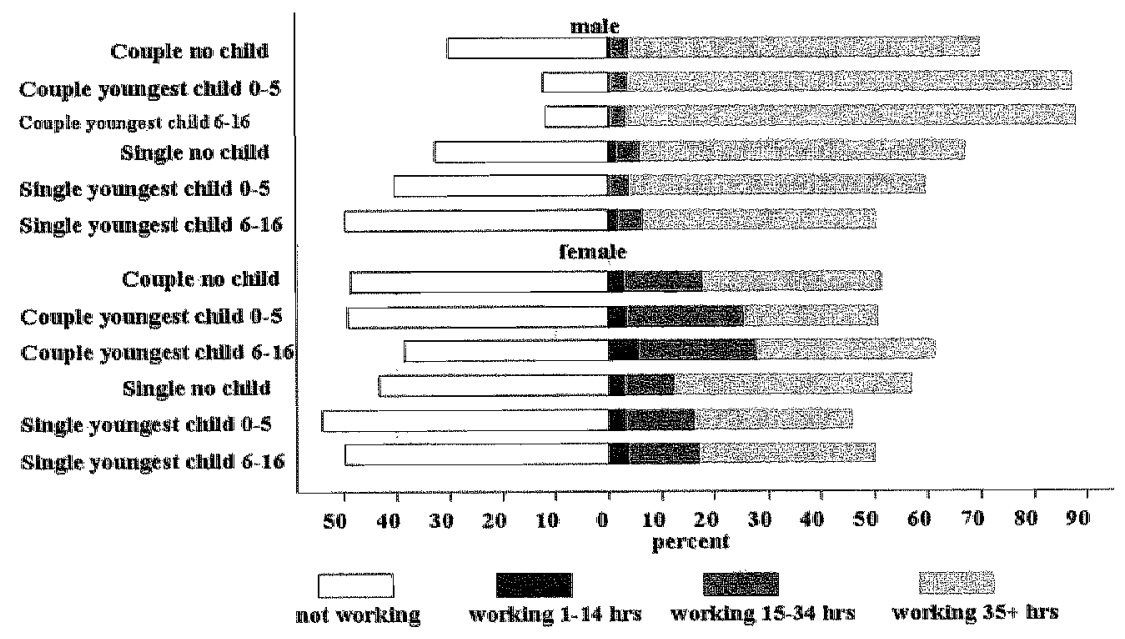

Source: ECHP, 1994-2001 (Eurostat); HHS, 1992-1997 (TARKD).

Figure 9.5 Labour market status and life course phase, males and females (18-64), 2001 (\%)

Overall, we see that the life course phase, however, does not have much of an impact on the number of hours worked in the case of males. For females, 
however, the life course phase has a larger effect on their labour supply in terms of hours.

For single females with children and females in a relationship without children or with young children we indeed find that they are more likely to withdraw and to become non-participants. But when females participate and when they have a partner they more often work in a part-time or a small parttime job especially if they have children.

\section{Transition rates}

Over time people tend to change their employment position as socioeconomic events (for example, unemployment, a job change or retirement) and socio-demographic events (for example, childbirth or marriage) require them to adapt their working time.

The changes in employment status over time are depicted in Table 9.3 for males and in Table 9.4 for females. In these tables we depict the transitions into another employment status after one, three and five years in the career.

Table 9.3 Transition rates in employment status after one year $(t+1)$, three $(t+3)$ and five years $(t+5)$, males $(18-64)(\%)$

\begin{tabular}{|c|c|c|c|c|c|}
\hline & \multicolumn{5}{|l|}{ Status in $t+1$} \\
\hline & Not working & 1-14thours & 15-34 hours & $35+$ hours & Total \\
\hline \multicolumn{6}{|l|}{ Status in $t$} \\
\hline Not working & 78 & 2 & 3 & 1.8 & 100 \\
\hline $1-14$ hours & 34 & 28 & 12 & 26 & 100 \\
\hline 15-34 hours & 17 & 3 & 47 & 34 & 100 \\
\hline \multirow[t]{2}{*}{$35+$ hours } & 7 & 0 & 2 & 91 & 100 \\
\hline & $\begin{array}{l}\text { Status in } t+3 \\
\text { Not working }\end{array}$ & 1-14 hours & $1.5-34$ hours & $35+$ hours & Totall \\
\hline \multicolumn{6}{|l|}{ Status in : } \\
\hline Not wotking & 65 & 2 & 4 & 30 & 100 \\
\hline $1-14$ hours & 28 & 14 & 13 & 45 & 100 \\
\hline 15-34 hours & 21 & 2 & 33 & 44 & 100 \\
\hline \multirow[t]{2}{*}{$35+$ hours } & 11 & 0 & 2 & 86 & 100 \\
\hline & $\begin{array}{l}\text { Status in } t+5 \\
\text { Not working }\end{array}$ & 1-14 hours & $15-34$ hours & $35+$ hours & Total \\
\hline $\begin{array}{l}\text { Status in t } \\
\text { Not working }\end{array}$ & & 2 & 5 & 40 & 100 \\
\hline $\begin{array}{l}\text { Not working } \\
1-14 \text { hours }\end{array}$ & $\begin{array}{l}53 \\
27\end{array}$ & 6 & $\| 1$ & 56 & 100 \\
\hline 15-34 hours & 23 & 1 & 27 & 49 & 100 \\
\hline $35+$ hours & 14 & 0 & 2 & 83 & 100 \\
\hline
\end{tabular}

Source: ECHP, 1994-2001 (Eurostat); HHS, 1992-1997 (TARK). 
It is obvious from the tables that the status of full-time employment of the large majority of males (91 per cent) is pretty stable from year to year, and so is the status of non-employment (although the group is smaller in size). Parttime statuses are less stable at least for males. Less than half of all males in part-time jobs (15-34 hours) in a particular year are still working part-time one year later. A third of them have made a transition into full-time employment. Statuses in small part-time jobs are even less stable since only 28 per cent are still working in such a job one year later. A third has stopped working and a quarter has made a transition into full-time employment after one year.

The stability in non-participation is larger among females; 86 per cent remain out of the labour force between year $t$ and the following year $t+1$. Female part-time employment (whether short or regular part-time) is also more stable than is the case for males: 47 per cent remain in their small parttime job and 69 per cent remain in their part-time job. This could mean that part-time employment is of a more persistent nature for females.

Table 9.4 Transition rates in employment status after one $(t+1)$, three $(1+3)$ and five years $(t+5)$, females $(18-64)(\%)$

\begin{tabular}{lccccc}
\hline & Status in $t+1$ & & & & \\
\cline { 2 - 6 } Status in $t$ & Not working & $1-14$ hours & $15-34$ hours & $35+$ hours & Total \\
\hline Not working & 86 & 2 & 4 & 7 & 100 \\
$1-14$ hours & 26 & 47 & 19 & 8 & 100 \\
$15-34$ hours & 13 & 4 & 69 & 14 & 100 \\
$35+$ hours & 9 & 1 & 6 & 84 & 100 \\
& Status in $t+3$ & & & & \\
Status in t & Not working & $1-14$ hours & $15-34$ hours & $35+$ hours & Total \\
Not working & 78 & 3 & 7 & 11 & 100 \\
$1-14$ thours & 30 & 32 & 23 & 14 & 100 \\
$15-34$ hours & 20 & 4 & 57 & 19 & 100 \\
$35+$ hours & 16 & 1 & 9 & 74 & 100 \\
& Status in $t+5$ & & & & \\
Status in t & Not working & $1-14$ hours & $1.5-34$ hours & $35+1$ hours & Total \\
Not working & 72 & 4 & 9 & 15 & 100 \\
$1-14$ hours & 32 & 24 & 27 & 17 & 100 \\
$15-34$ houts & 24 & 4 & 49 & 22 & 100 \\
$35+$ hours & 21 & 1 & 11 & 67 & 100 \\
\hline
\end{tabular}

Sounce: ECHP, 1994-2001 (Eurostat); HHS, 1992-1997 (TARKI).

When the observation period is extended up to three or five years the working-time statuses on the labour market appear less stable because, as the years go by, there are more opportunities for people to adjust their labour supply on the labour market in accordance with their preferences or by 
adapting to external constraints. The differences between males and females appear to be larger as the observation period is extended up to three or five years. Significantly fewer females remain in full-time paid employment in the five years time horizon, and more of them make a transition out of employment.

However, as time passes, there are also more females who make a transition from part-time employment (whether snall part-time or not) into full-time employment. Among females, the transition from part-time enployment to full-time employment is least often occurring in the Netherlands and most often in Finland, Hungary, and Spain.

In Table 9.5, we report on the issue to what extent the transition for fernales from part-time employment to full-time employment is associated with the main reason why they work part-time.

Table 9.5 Transition rates in employment status after one year, three and five years for females (18-64) according to the reason why they work part-time in the current year (\%)

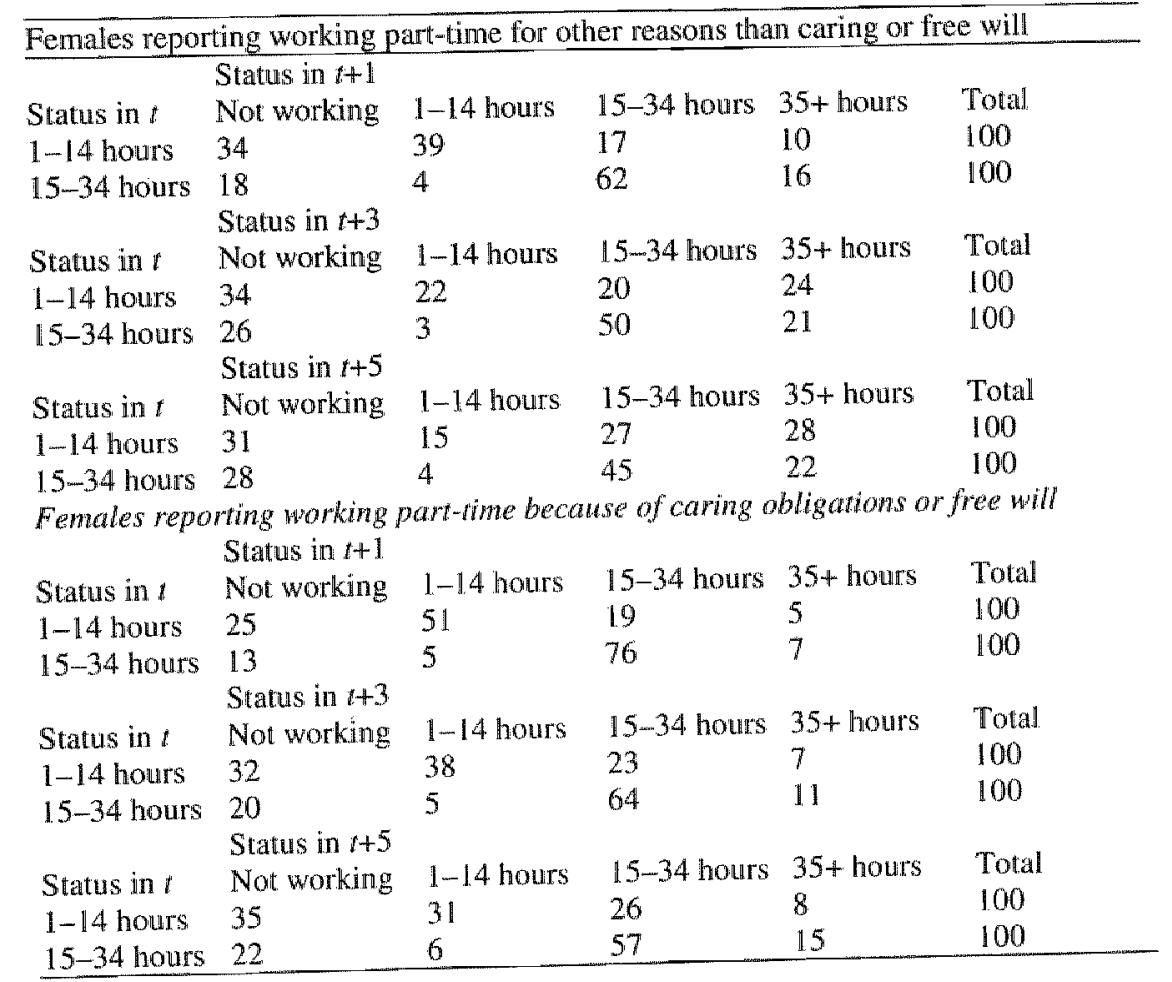

Source: ECHP, 1994-2001 (Eurostat). 
Using the reasons as reported in Figure 9.4 , we define a variable indicating whether or not females work less than full-time out of free will or because of caring obligations ('does not want to work more hours, works part-time because of household activities or caring obligations"), or because of other reasons (education, cannot find full-time job, personal illness or other reason). ${ }^{7}$ On the one hand, Table 9.5 shows that transitions into full-time employment are more common for females reporting part-time employment for other reasons than caring obligations (or free will). This seems to be the case even in the medium-term ( 5 years) although the difference between the two groups is smaller than in the short-term ( 1 year). On the other hand, it is also illustrated that in the short-lerm, females not reporting care as the reason why they work part-time, are more likely to leave paid employment. However, the difference between the two groups is smaller in the medium term.

\subsection{MODEL ESTIMATES}

\subsubsection{Model}

Having described patterns of part-time employment in Europe and transitions across employment statuses, we now turn to modelling changes in the employment status over time. To do so, we estimate a multinomial logit model for the employment status after one, three and five years $(t+1, t+3$ and $t+5)$, controlling for the number of hours worked in $t$ and a number of covariates. As in the previous paragraph, the hours are categorised in nonparticipation, small part-time jobs (1-14 hours worked), part-time jobs (1534 hours worked), and fulll-time jobs (working 35 hours or more). The multinomial logit model that is estimated distinguishes among these various employment statuses (see Box 9.1).

In order to test expectation I, we consider part-time employment as the base category in the model. Furthermore, we set the reference category for the current employment status to full-time workers. In doing so, the estimated parameters can be interpreted as the difference in the probability of being employed full-time in the future for the workers who are currently not enployed full-time.

Two variables that are specifically related to caring obligations enter the model: the variable indicating the life course phase and a clummy variable indicating whether or not one works less than full-time out of free will (does not want to work more hours, works part-time because of household activities or caring obligations). ${ }^{8}$ Furthermore, the model controls for personal characteristics (age, educational level, health status, and past history of unemployment), as well as job characteristics (sector of activity, number of 
employees in the firm). Year dummies are also included in order to capture aconomic cycle effects. Controlling for such background chamacteristics is important for workers in part-time jobs might be a selective group.

\section{Box 9.1 The multinomal model}

The probability of being wn either state (non-participation, small part-time job, fulltime), as compared to the reference state (regular part-time), is given by the following equation:

$$
P(y=j)=\frac{\exp \left(\sum_{k=1}^{K} \beta_{j k} x_{k}+\gamma_{j} s_{4}\right)}{1+\sum_{j=1}^{j-1} \exp \left(\sum_{k=1}^{K} \beta_{j k} x_{k}+\gamma_{j} s_{i}\right.}
$$

with $J=4$ (the four labour market stanses), $j=$ part-time being the reference state and $K$ the number of explanatory variables $x$. The variables included in the model are:

- Hours worked in $f:$ non-participation, small part-time, regulan" part-time, full-time (reference);

- Household ype: couple without child (reference), couple youngest child $0-5$, couple youngest chill $6-16$, single no child, single youngest child $0-5$, single youngest child 6-16;

- Part-time for caring: dummy for people who do not want to work more hours, or work part-time because of household activities or caring obligations;

- Age and age squared (100);

- Education level: low, average (references), high;

- Bad health: dummy for people bad or very bad health;

- Public sector: dummy for people working in the public sector (coded 0 for people out of employment);

- Firm size: number of people working in the company (coded 0 for people out of employment);

- Past unemployment: dummy for people reporting unemployment in the past 5 years;

- Year dummies;

- Country dummies.

- Indicators for labour market opportunities: numerical flexibility and employment security.

\subsubsection{Results}

\section{Employment status}

The results of the estimation of the multinomial model are represented in Table 9.6. ${ }^{10}$ They show that relative to full-time workers, part-time employees have a lower probability of being employed full-time one year later. The size of the effect shows that it does not matter much whether the part-time 


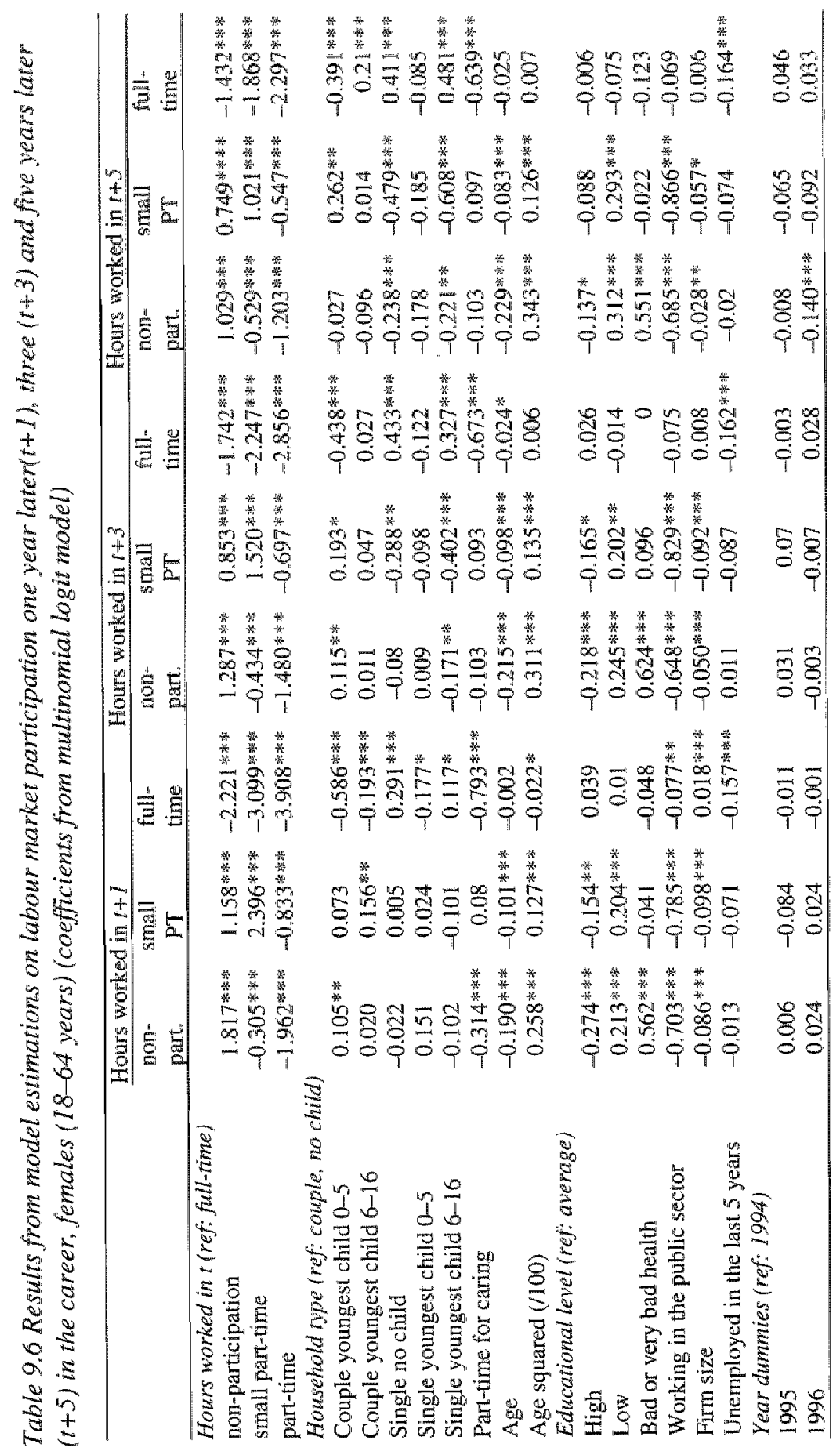




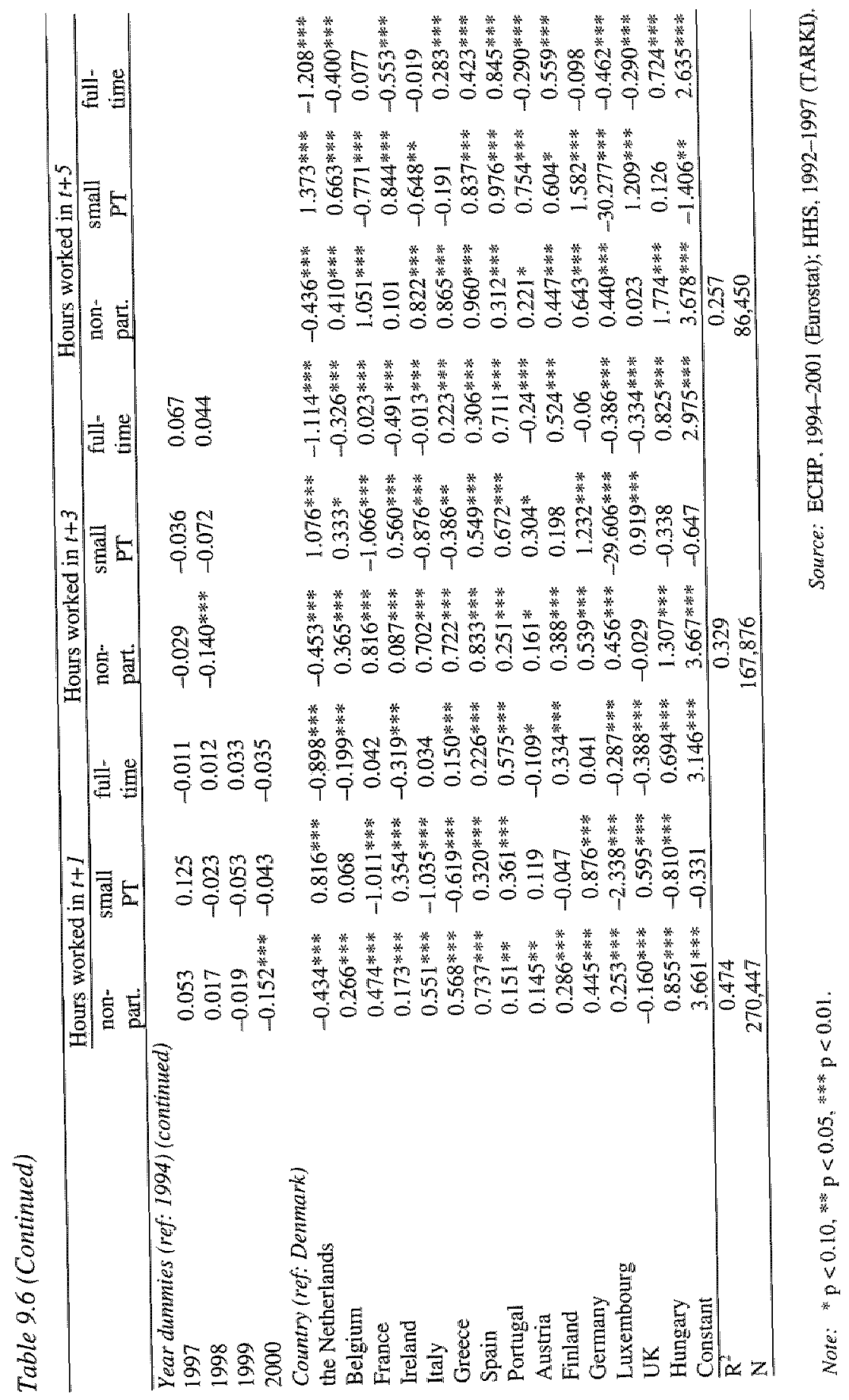


job is a short-hours or a regular job. Because all coefficients of the exit states of part-time employed females are negative, we can conclude that part-time is an absorbing state from which few people leave. This confirms the results from the descriptive part showing that the majority of females working parttime in a particular year remain in part-time employment one year later.

Furthermore, the results show that looking at the medium-term effects (after three and five years), we observe that the probability of part-timers being engaged in full-time jobs is still lower than that of full-timers but the 'scarring effect' is diminishing in size (from -3.908 for full-time employment after one year to -2.297 after five years). Whether or not we can speak of a true scarring effect depends on the extent to which being in part-time employment is the result of constraints on the labour market. If working parttime is out of free will, then cannot speak of scarring. The estimates show that respondents who work part-time because of caring obligations or because they simply do not want to work more hours are less likely to be engaged in full-time employment in the future. This effect persists over time. Mothers with children between the ages of 6 and 16 are more likely to make a transition into full-time employment, probably because as children grow older, it becomes easier to combine full-time employment and caring obligations."

Females who currently work part-time because of caring obligations or because of housework are significantly less likely to make a transition to fulltime employment. ${ }^{12}$ The effect does not slow down much as one looks ahead in the career one, three and five years later. On the one hand, this shows that working part-time offers females a relatively strong attachment to the labour market and that their strategy of working part-time is indeed associated with the stage of the life course they are in rellecting their need to combine work and care. On the other hand, the results show that the opportunities for fulltime employment for caring mothers are still poor, even in the medium term. In the medium term, Dutch females in particular are less likely to be engaged in full-time employment, but they are also less likely to exit to nonemployment compared to Danish females (see also Fouarge and Baaijens, 2006). Engaging in a full-time job is also less likely to happen in Belgium, Ireland, Austria, Luxembourg and the UK. On the contrary, females in the Southern European countries (especially Portugal), Hungary and Finland are more likely than Danish females to be working in a full-time job in the medium-term. This reflects the cross-sectional evidence discussed above. 


\subsection{EFFECT OF CHILDBIRTH ON HOURS WORKED}

The birth of a child is a major life course event that affects young parents' personal and social life. Such an event, howewer, has potentially also an impact on parent's working time. In particular, the new-born child and infants require additional care which might reduce the time available for labour market participation. In this section, we focus on the effect of childbirth on the labour supply of young parents. The analyses are performed on a sample that only included people from 18 to 45 years of age, as this is the most relevant group when it comes to childbirth.

In Figure 9.6, we use the pooled dataset to depict the average number of hours worked in the year of childbirth, as well as up to 3 years prior and after childbirth. ${ }^{13}$

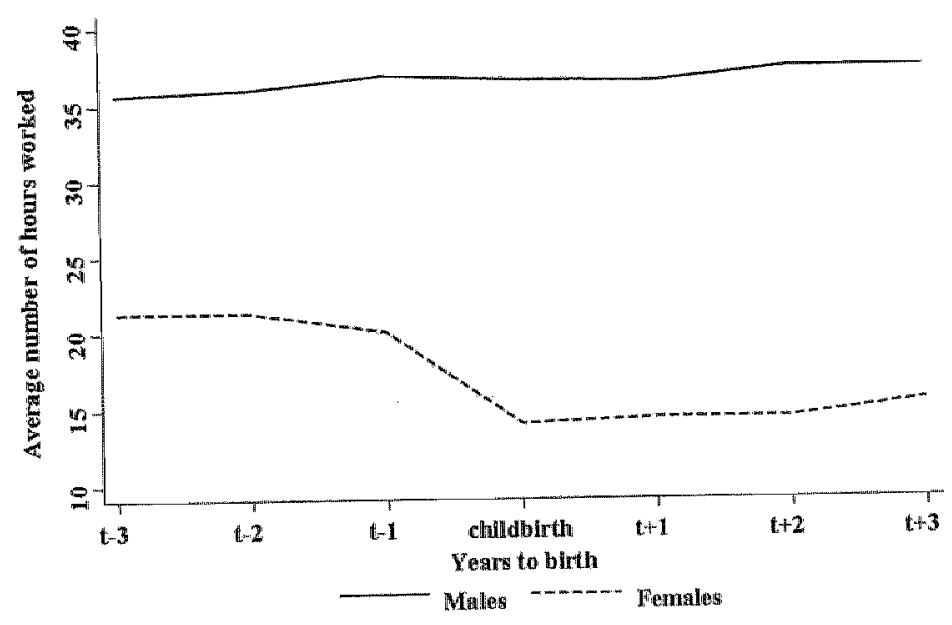

Source: ECHP. 1994h-2001 (Eurostat); HHS, 1992-1997 (TARKI).

Figure 9.6 Average number of working hours of working males and females before and after childbirth, aged $18-45$ years old

All respondents becoming parents are included, irrespective of their labour market status. Respondents who are not engaged in paid employment are assumed to work zero hours. Henceforth, the lines in the graph are the combined effect of (1) respondents reducing their number of hours, and (2) respondents withdrawing from the labour market.

As the figure shows, childbirth has no effect on the labour supply (working hours) of fathers. Mothers do adapt their labour supply with an average decrease in working hours that amounts to 5 hours per week. There 
seems to be an anticipation effect (with females already reducing their labour supply as childbirth approaches) and a small recovery effect (with a small increase in the labour supply three years after childbirth).

In order to better understand the total effect as depicted in Figure 9.6, we have computed the labour market status and working hours two years before and two years after childbirth. Moreover, the computation was done for females having their first child and for females who already had children before giving birth to another child. The results are represented in Figure 9.7.

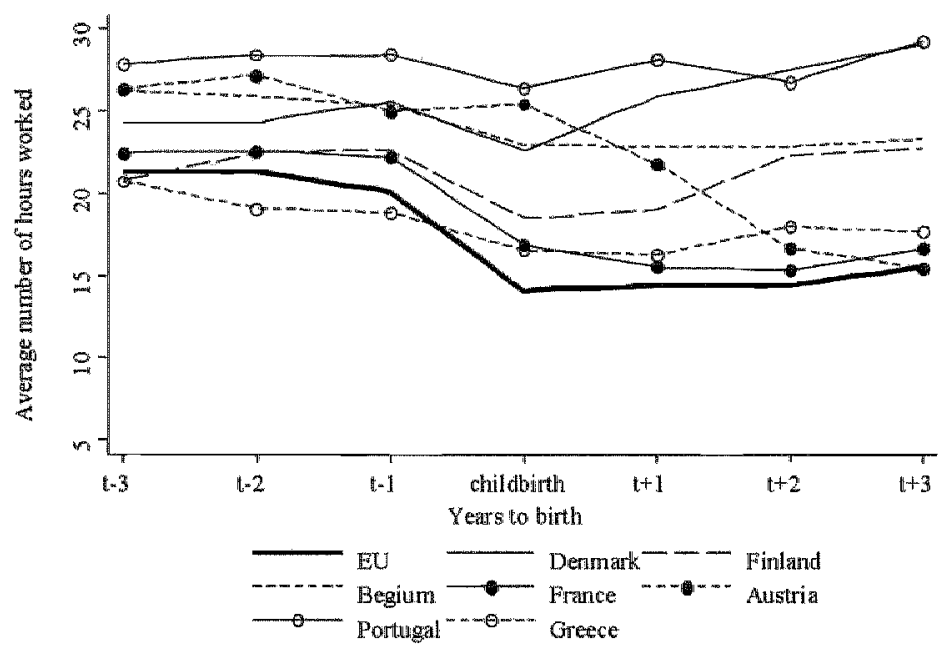

Source: ECHP, 1994-2001 (Eurostat); HHS, 1992-1997 (TARKR).

Figure 9.7 Labour market status of young mothers (18-45), 2 years before and 2 years after childbirth (percentages)

First it is important to note that the participation prior to and after childbirth is higher for females who gave birth to their first child. Moreover, females who already have children are more likely to work part-time. The reason for this is that having more than one child makes it even more difficult to combine caring obligations and employment. Second, as the figure shows, the reduction in the average number of hours worked as depicted in Figure 9.6 is due to two changes in the labour supply of females following birth. On the one hand, the largest part of the effect on average hours is due to females withdrawing from the labour market. This is the case for females giving birth to their first child - their participation rate drops significantly - but it is also the case for females giving birth to additional children. On the other hand, the drop in hours is also party explained by the reduction in the number of hours worked by females giving birth to their first child. 
The effect of childbirth on the labour supply of young females (hours worked) varies significantly among countries. In Figure 9.8, we have plotted. the average number of working hours before and after childbirth for countries where the effect of childbirth on working hours is below average in the EU. ${ }^{14}$ Figure 9.9 contains the same plot for countries where the effect of childbirth on hours worked is above average in the EU.

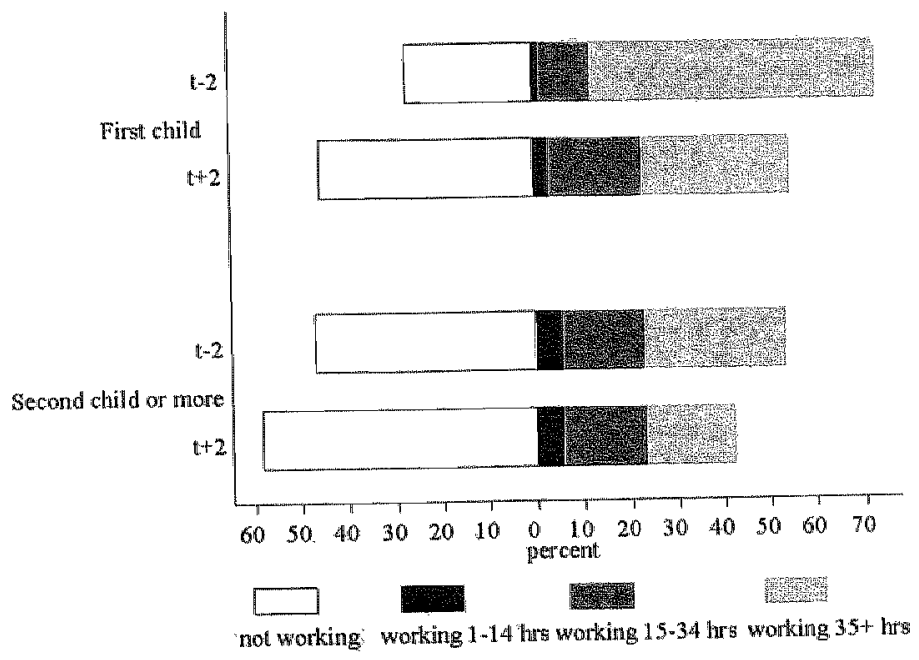

Source: ECHP, 1994-2001 (Eurostat); HHS, 1992 1997 (TARKI).

Figure 9.8 Average number of working hours of females (18-45) before and after childbirth in 7 countries (effect is below EU average)

In two countries, Portugall and Denmark, childbirth does not lead to a permanent decrease in the number of hours worked by females (see Figure 9.8). In Greece and Belgium, the reduction in working hours is relatively small whereas in Finland the reduction is only temporary while females return to their pre-birth level of working hours within two years following childbirth.

In the other group of countries (Figure 9.9), two countries show a remarkable pattern of pre- and post birth participation. In Germany and Hungary, the number of hours worked drops significantly in the year of childbirth because many females withdraw from the labour market. Participation only recowers slightly in the years following childbirth. In fact, the sharp decrease in the number of hours worked among German and Hungarian females following childbirth is the result of a significant withdrawal from the labour market. Generally speaking, where the labour market participation rate 
of young mothers is high prior to childbirth such as in Denmark, the Netherlands, Belgium and Portugal (major exceptions are Austria and Hungary), it tends to remain high even after childbirth. However, in Denmark, the Netherlands and Belgium this goes along with a significant increase in part-time employment, but not in Portugal. We might contend that the role of institutional support to working mothers for allowing them to keep on working and not to withdraw nearly fully is important in this respect. In countries where the level of institutional support is high such as in Denmark and the Netherlands women tend not to withdraw fully and to stay longer in part-time work than in countries where such support is lacking.

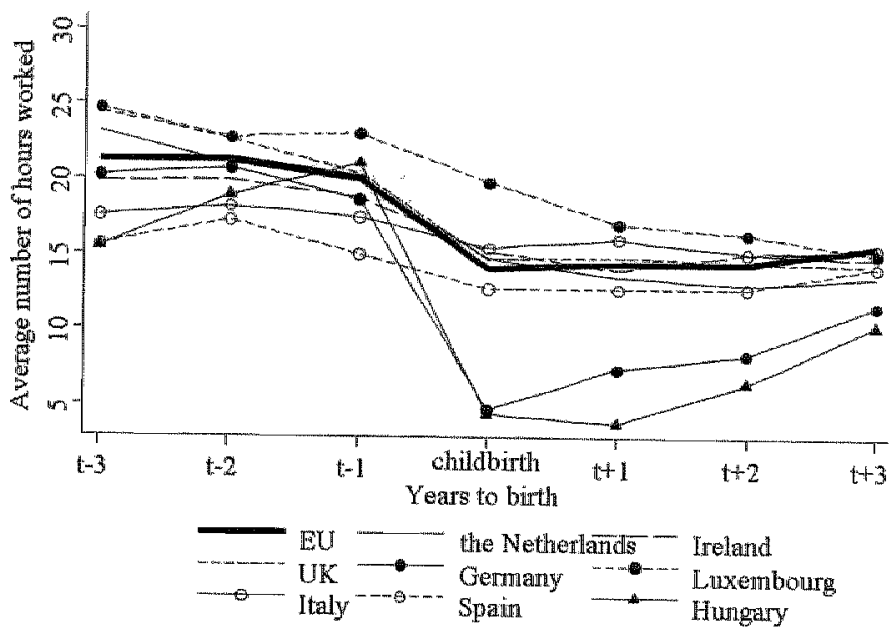

Source: ECHP, 1994-2001 (Eurostat); HHS, 1992-1997 (TARKI).

Figure 9.9 Average number of working hours of females (18-45) before and after childbirth in 8 countries (effect is above EU average)

\subsection{INCOME AND SOCIAL TRANSFERS}

\subsubsection{Income in Various Stages of the Life course}

In two studies of Anxo et al. (2005) and Klammer and Keuzenkamp (2005), the ECHP data were used to assess the impact of social transfers on household income. The conclusion then was that 'social security benefits are mainly concentrated in two phases of life: when people have children in the household and during retirement, when people are 60 years or older.' (Klammer and Keuzenkamp, 2005, p. 61; see also Anxo et al., 2005, p. 59-63). 
Here, we focus on the composition of individual income of young females and find that social security benefits are especially important in the life phase in which females raise children, but especially when they have to do that alone as single mothers (Figure 9.10). ${ }^{15}$

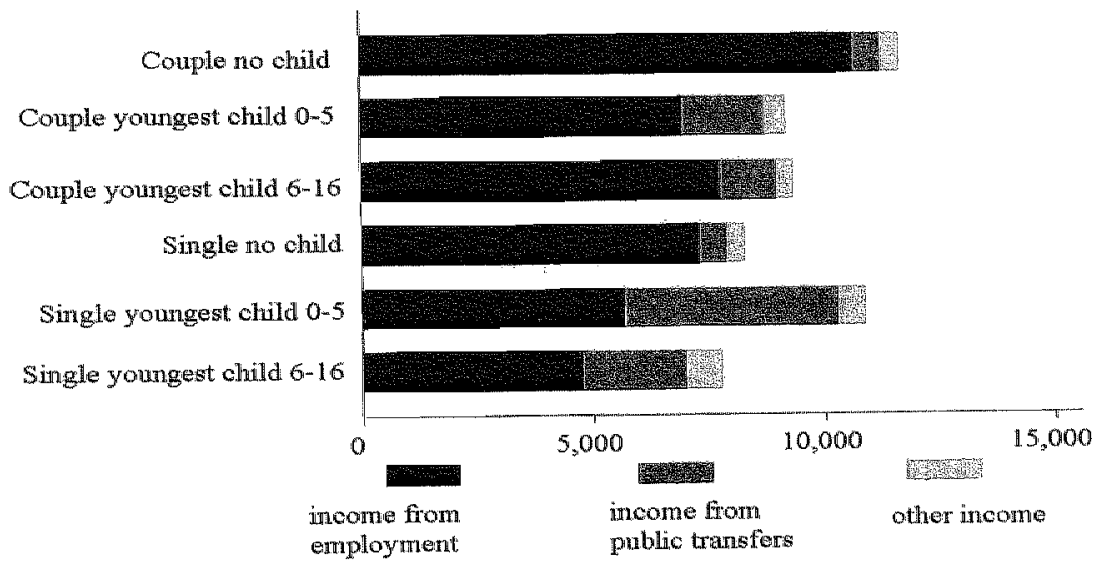

Source: ECHP, 1994-2001 (Eurostat); HHS, 1992-1997 (TARKI).

Figure 9.10 Composition of the personal income of young fernales (18-45) by household type in 2001 (in 2000 for PPP corrected euros)

Figure 9.10 reveals a similar static view on the life course as in the approach of Klammer and Keuzenkamp (2005) and Anxo et al. (2005). The evidence suggests that people go through the various life stages though respondents are only observed in one of these stages. To circumvent this problem, we have opted for a dynamic view on the life course by using real longitudinal data and by focusing on the effects over time of a particular but significant life course event (childbirth) on net personal income.

\subsubsection{Income Effect of Childbirth}

To assess the effect of (an increase in) caring obligations we computed preand post birth total net yearly personal income, the net yearly personal income from employment, and the net yearly personal income from public transfers. The yearly income from employment and from public transfers is zero when no income of such type is received by the respondent. The results are presented in Figure 9.11 for females aged 18 to 45 years and giving birth during the observation period. 


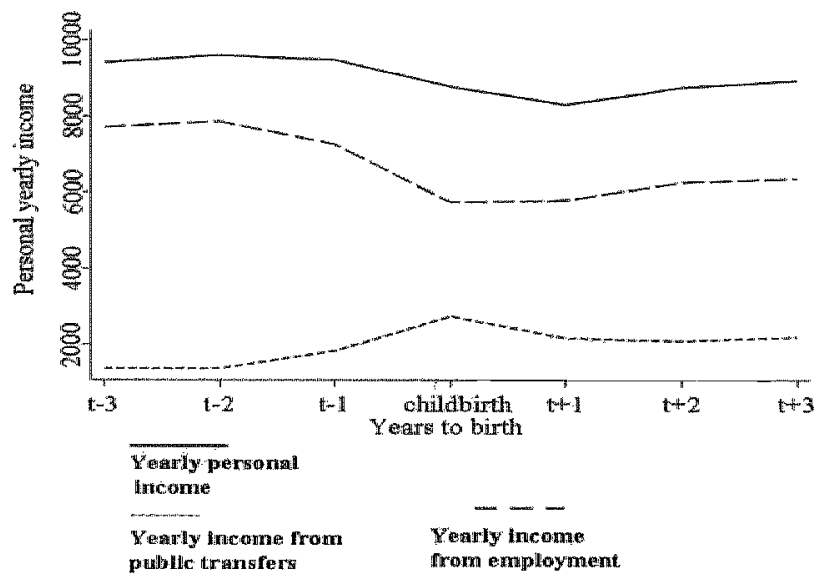

Source: ECHP. 1994-2001 (Eurostat); HHS, 1992-1997 (TARKI).

Figure 9.11 Pre and post birth yearly net personal income, all females aged $18-45$ years (in 2000 for purchasing power parities corrected euros)

The figure shows that the yearly income from employment drops from some 8,000 euro in the years prior to childbirth to approximately 6,000 euro in the years following. This, of course is an average for all mothers and the income drop from employment is the combined effect of several things: (1) of the true evolution of the incomes of working females, (2) the reduction in female labour supply (see above) with a downsizing effect on the yearly wage, and 3) the withdrawal of females from the labour market (in which case the income drops to zero).

For females who remain in employment, the effect is less dramatic (Figure 9.12 ) and the reduction is either the result of a reduction in the number of hours worked (which reduces yearly income), or the result of a change in hourly earnings after childbirth, or a mix of these two effects. Childbirth does result in a permanent lower level of income from employment on a yearly basis due to the permanent reduction in the number of hours worked per week as it was depicted in Figure 9.6. The reduction in labour income is only partly compensated by an average increase in the incorme from public transfers (see Figure 9.11). Henceforth, the total effect of childbirth on net personal income is negative but less negative than the effect on net labour income. 


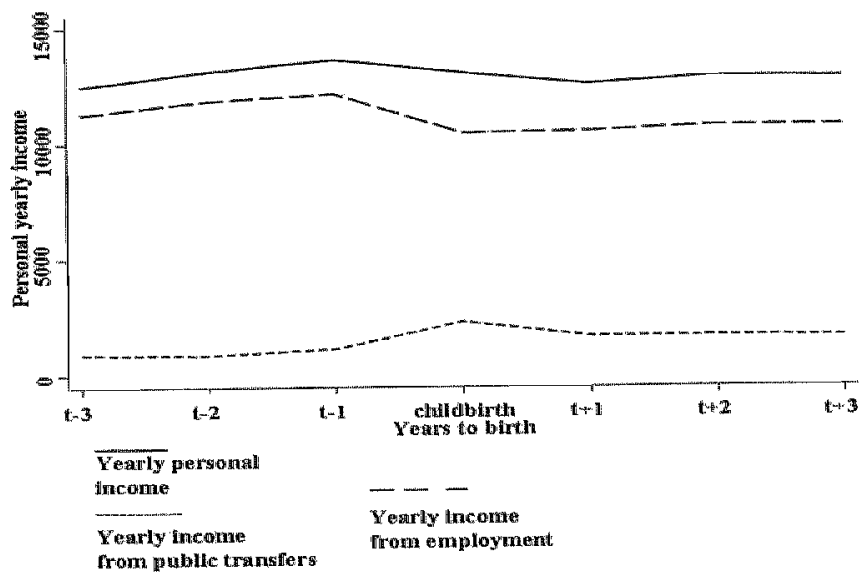

Source: ECHP, 1994-2001 (Eurostat); HHS, 1992-1997 (TARKI).

Figure 9.12 Pre and post birth yearly income, females aged 18-45 who remained employed (in 2000 for PPP corrected euros)

\subsubsection{Modelling the Effect of Childbirth on Income}

To assess the effect of childbirth on female labour income, we have then estimated a regression model on annual net personal labour income. We estimated a fixed-effects panel regression model that is explained in Box 9.2. The results are presented in Table 9.7.

Because of our focus on the effect of childbirth on female labour income, the mode] was estimated for females only who remained in paid employment and who did not drop out. Though increasingly so women tend to stay in employment after childbirth, the results are still not generally applicable to other females. ${ }^{16}$ The estimates show that net of observed and unobserved time constant characteristics, childbirth has a significant negative effect on net yearly personal income from employment. The birth of a child reduces the net labour market income by some 5 per cent $(-0.218 / 4.056)$.

The effect of childbirth on reducing the yearly wage income is rather strong as the first model shows. The second model with the country dummies included show that the childbirth effect is stronger in Austria and Finland than in the reference country Denmark, while the income loss is less than in Denmark in the Netherlands, Italy, Greece, Luxembourg and the UK. In Portugal, the yearly income after childbirth is larger than before childbirth. The reasons for these differences across counties are associated with the functioning of the labour market, the generosity of the transfer system and the 


\section{Box 9.2 The panel regression model}

Our clata contain information on the annual income of an individual $i$ at each time point (year). Panel data techniques make use of this particular type of data structure and enable us to model the dependent variable (income) as a function of observed time varying characteristics in the data - such as the occurrence of a childbirth - and unobserved time constani characteristics of the respondents. The fixed-effects panel model estimated has the following form:

$$
y_{i s}=\alpha+\beta x_{i t}+\mu_{i}+\varepsilon_{i s}
$$

where $y_{i t}$ is the annual income of individual $i$ at time $t, x_{i t}$ is a set of time varying covariates, $\alpha$ is a constant term, $\mu_{i}$ is an individual specific unobserved effect, and $\varepsilon_{i l}$ is an error term with standard properties. $\mu_{i}$ can be identified because of the repeated measurement in the data, and it is not correlated to the error. Because we use a fixed effects specification we do allow for possible correlation between the fixed effects and other covariates in the model. Such a model better allows for a causal interpretation of the effect of childbirth on income than would a regular regression model do. The estimated parameter Sigma $\mu$ is an estimate of the standard deviation of the individual specific error, and Sigma $\varepsilon$ stands for the standard error of the error term. The amount of error in the model that is due to individual unobserved variation in the data is tepresented by Rho (Sigma $\mu /$ $\left((\text { Signa } \mu)^{2}+(\text { Sigma } \varepsilon)^{2}\right)$. It provides an indication for the relevance of applying such a model on the data. The variables included in the model are:

- A dummy for childbirth;

- A dummy for single mothers;

- Number of hours worked per week;

- Age and age squared $(/ 100)$;

- Education level: low, average (reference category), high;

- Bad health: dummy for people having a bad or a very bad health;

- Public sector: dummy for people working in the public sector (coded 0 for people out of employment);

- Firm size: number of people working in the company (coded 0 for people out of employment);

- Past unemployment: dununy for people reporting unemployment in the past 5 years;

- Year dummies;

- Country dummies (that we also interact with the childbirth dummy). 
Table 9.7 Fixed effects panel regression model on yearly income, females (18-45 years), 1994-2001 (beta coefficients)

\begin{tabular}{|c|c|c|}
\hline \multirow[b]{2}{*}{ Single } & \multicolumn{2}{|c|}{ Yearly wage income } \\
\hline & $\overline{0.042}$ & 0.044 \\
\hline Hours worked per week (latg) & $0.204 * *$ & 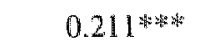 \\
\hline Age & $0.174 * \cdots$ & 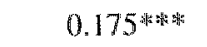 \\
\hline Age squared $(/ 100)$ & $-0.169^{\text {*小水 }}$ & 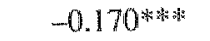 \\
\hline Educational lewel (ref: average) & & \\
\hline High & $0,085 *$ & 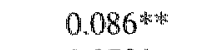 \\
\hline Low & $-0.073^{*}$ & $-0.070^{*}$ \\
\hline Bad or very bad heath & $-0.087 *$ & $-0.085^{*}$ \\
\hline Working in the public sector & 0.04 & 0.038 \\
\hline Firm size & 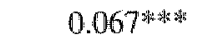 & 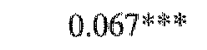 \\
\hline Unemployed in the last 5 years & -0.103 & -0.101 \\
\hline Year dummies (ref: 2000 ) & & \\
\hline 1995 & 0.01 & 0.004 \\
\hline 1996 & 0.022 & 0.019 \\
\hline 1997 & 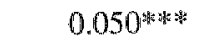 & $0.050^{* * * * *}$ \\
\hline 1998 & 0.01 & 0.012 \\
\hline 1999 & 0.013 & 0.014 \\
\hline Childbirth & $-0.218^{3}$ & \\
\hline Childbirth * Country (ref: Denmark) & & 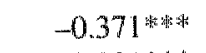 \\
\hline Netherlands & & 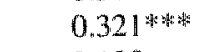 \\
\hline Belgium & & 0.188 \\
\hline France & & 0.145 \\
\hline Ireland & & 0.192 \\
\hline Itally & & $0.209 *$ \\
\hline Greece & & $0.363^{\text {***⿲二丨匕 }}$ \\
\hline Spain & & $0 . \Perp 32$ \\
\hline Portugal & & $0.486^{6 y^{2}}$ \\
\hline Austria & & 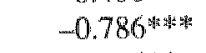 \\
\hline Finland & & $-0.314 *$ \\
\hline Germany & & -0.1 \\
\hline Luxembourg & & $0.252^{*}$ \\
\hline UK & & $0.239^{\text {: 水 }}$ \\
\hline Hungary & & 0.497 \\
\hline Constant & 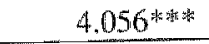 & 4.032 非非和 \\
\hline $\mathrm{R}^{2}$ & 0.016 & 0.018 \\
\hline $\mathbb{N}$ & 68,354 & 68,354 \\
\hline Sigma y & 1.868 & 1.865 \\
\hline Sigma & 1.149 & 1.148 \\
\hline Rho & 0.725 & 0.725 \\
\hline
\end{tabular}

Note: $p<0.10, * 0<0.05$, $p<0<0.001$.

Source: ECHP, 1994-2001 (Eurostat); HHS, 1992-1997 (TARKD). 
supporting role of families or social networks. According to Anxo et al. (2005) using cross-sectional data particularly in Sweden - more so than in the Netherlands or the UK - the transfer system appeared capable to compensate the earnings loss of women with young children (under seven) almost completely. The findings presented here point to the impact of institutional support mechanisms to cushion the earnings losses due to childbirth and caring duties.

The other variables included in the model show that investments in human capital pay off for women since the yearly wage income is higher for higher educated and lower for lower educated women. Women who keep on working long hours after childbirth obviously have a higher yearly wage income than women who reduce working hours more. Also the results by age confirm our predictions from the human capital theory: as experience (or age) increases, income also increases, but at a decreasing rate.

After some age threshold earnings tend to fall again probably while for older women it is harder to return into employment in longer hours jobs. For the same reason women reporting bad health end up with a lower yearly income, due to loss of productivity and hence of human capital. Women working in larger firms are either better paid, even after controlling for education level, age and health, or are capable of maintaining longer working hours because of which their earnings losses are lower. This might just reflect the better child care facilities in larger firms compared to smaller firms.

\subsection{CONCLUSIONS}

In this chapter, it is shown that the reasons why men and women choose to work part-time are rather different. The different reasons constitute one of the explanations why the share of part-time employment among males and females are markedly different. It also partly explains why the use of it is also very diverse across Europe. Females tend to use part-time employment for the purpose of combining employment with caring obligations, whereas males report very different reasons for working part-time showing their dissimilar work strategies compared to females. This is also shown in the transition rates out of part-time work. Females, more often than males, tend to remain in part-time employment whereas men tend to move to longer hours jobs. Therefore, the conclusion to be drawn is that males consider a part-time job to be a transitory state towards full-time employment and not a quasi-permanent state as it is for quite a number of women. This seems particularly the case in countries where part-lime work tends to become the norm for women such as in the Netherlands where most women work parttime. If we observe the differences across Europe it turns out that overall in 
Europe only 7.5 per cent of European male workers were employed in a parttime job, but more than a third of females. The percentage of females in parttime jobs however varies largely across Europe; it appeared lowest in Slovakia (4.1. per cent) and largest in the Netherlands ( 75 per cent).

We have examined several of our expectations associated with the socalled 'scarring' thesis. First of all, we expected part-time workers to have a lower probability to be in full-time employment later in the career than fulltime workers; this is indeed confirmed, but this 'negative' effect becomes smaller as the observation period is extended. Second, we assumed that parttimers due to building up less human capital during their part-time career are more likely to make a transition into non-employment later in the career; this is also confirmed. Third, we contended that this effect becomes smaller over time and indeed the effect tends to diminish as we extend the period of observation. However, whether or not this point to a scarring effect of parttime work on the future employment career depends also on the fact whether part-time is considered an involuntary state for the occupants or not. In the case where it is voluntary, people choose for part-time work because if fulfils someone's preferences better. We examined the reasons why people opt for part-time work. Our analyses show that women who are working part-time because they report 'not wanting to work more hours' or "because of caring obligations' are less likely to make a transition into full-time employment later in the career. This result appears robust even if we extend the time horizon. This corroborates again one of our expectations with respect to the role assigned to personal preferences for working part-time. Support for this is also found in the observation that when children grow older, the transition into full-time employment seems to become less unlikely. Obviously, people are better able by that stage in the life course to meet their preferences for working more hours although it might take some time to achieve that. However, working part-time is not only a matter of free choice. We also find that a significant proportion of females in Southern Member States, France, Belgium and Finland report to work part-time because of constraints in the labour supply.

Corresponding to our expectation, our analyses also show that childbirth has a sizeable effect on female labour market participation. The common pattern is that females who become mothers are more likely to drop out of the labour market. They are also more likely to reduce working hours and to work part-time before and after childbirth. However, our analysis reveals major country differences. In countries such as Germany and Hungary, but also in Austria, France and the UK, mothers are more likely to withdraw more or less fully from paid employment due to childbirth than in other EU countries. This might point to lack of institutional support to working mothers to allow them to stay in employment. In countries with more support 
for working mothers such as in Denmark and also the Netherlands we see that full withdrawal is less likely to occur but also that women tend to remain in part-time work and not to move into full-time employment.

The birth of a child is also associated with a reduction in labour market income or earnings. To some extent, this is the consequence of the fact that a portion of women withdraw from the labour market. The more they tend to withdraw and the less income support is available in a country, the higher the income consequences of chilldbirth are. But we find that even for women who remain in paid employment after childbirth, the yearly labour income is lower after childbirth than before. Public transfers seem to exert a cushion effect on the income reduction due to childbirth because of which the income shortfall due to childbirth is smaller. We estimated that the birth of a child reduces the yearly wage income by about 5 per cent as calculated over the eight year period. We also find that the income penalty differs strongly across countries; it appears lowest in the Netherlands, Luxembourg and the UK but also in the southern countries ltaly, Greece and Portugal. The reasons might be very different for the various countries: in the UK it might be the efficiently functioning labour market allowing women to recover quickly from the initial drop in hours; in Sweden it might be the generous parental leave system (Anxo el al., 2005); in the Netherlands and Luxembourg it might be the generosity of the income transfer system and in the Southern countries it might be the family compensating for the initial earnings loss or the informal economy, but all this needs further scrutiny.

The overall conclusion seems to be that the role of institutions and policies in supporting working mothers through employment and income support plays a crucial role in avoiding scarring effects and in allowing women to realise their preferences for working part-time.

\section{NOTES}

1. The research was carried ou in the framework of a research project sponsored by the European Foundation for Living snd Working Conditions in Dublin. We gratefully acknowtedge their invaluable support and contribution to the project. Some findings treported here were alreadly publisthed in the final report (Muffells at al., 2007). The data for the project were provided by Eurostat and used with their permission. However, the data provider bears no responsibility for the analyses on interpretations presented in this study. The data included for Sweden are cross-sections and are not used in this chapter.

2. The British Household Panell Study (BHPS) for the UK, the German Socio-Economic Panel (GSOEP) for Germany, and the Panel Socio-économique / Liewen zu Lëtzebuerg (PSELL II) for Lnxenbourg.

3. Note, however, that only a few respondents report such low number of hours in the case of Hungary.

4. This corresponds to findings based on oher sources. See for example Eurostat Press Release of 10 September 2004 . 
5. Note that the percentages in the figure do not represent the share of part-time employment as such. The figure sbows that around 50 per cent of females are employed in part-time jobs in the Netherlands, for example. The share of part-time employment in total employment, is of course much larger, approximately 75 per cent.

6. Note that for females our estimates for part time enployment (share of females in pant-time employment) are similarr to the Eurostat estimates (Figure 1), but we do overestimate the proportion of females in part-rime jobs in freland, Greece. and to a lesser extent Hungary. For males, our estimate of the share of femalles working part-time is on average lower than the Eurostat numbers in Figure 9.1.

7. Obviously, the table does not include the countries for which the information is not available.

8. This dumny variable is coded 0 for the countries lacking this information (the UK, Luxembourg and Hungary). It is also coded 0 for people who work part-time according to our definition but for whom the reason why they work part-lime is not known tremember that the question in the ECHP was only asked to people working less than 30 hours per week).

9. The health status and the number of employees in the firm are lacking for Hungary. Pust unemployment (having been unemployed in the past 5 years) is missing for Hungary and Luxembourg. These wariables are not modelled for those countries.

10. The models include variables that are only defined for people in enployment for example firm size, and the public sector dummy). These wariables are only modelled for females in employment.

11. See Fouarge (2006) for similar evidence concerning the re-entry probability of non-working females in the Dutch labour market.

12. In the model, this is measured by a dummy taking the value for females reporting they work less than full-time because of housework or because they look after their children or because they do not want to work more hours (see Figure 9.7). This wariable is code 0 for femalles reporting another reason for working part-time and in countries where the information is not available.

13. Childbirth is detined as a birth occurring between $t-1$ and $t$. This could be a first child or an additional child being bom in a household.

14. In each graph, we depict the average effect of childbirth on hours worked in the EU.

15. All incomes measured in the ECHP and the Hungarian panel refer to lagt years' ineome.

16. Again, one should keep in mind that the analyses only apply to females who were and remained in paid employment prior to childbirth, in the year of childbirth and in the year after childbirth. Hence, the analyses does not accoumit for self-selection into employment, neither do they account for the endogeneity of childbirth itself, that is, that the planning of childbirth might be dependent on the tabour marthet position and the wage itself.

\section{REFERENCES}

Anxo, D., Boulin, J.-Y., Fagan, C. (2005), Working time options over the life conste: New work patterns and company strategies, European Foundation, Luxembourg: Office for Official Publications of the European Communities, 145 .

Becker, G. (1964), Human Capiral, A Theoretical and Empirical Analysis with Special Reference to Education, New York: National Bureau of Economic Research, Chicago, University of Chicago Press.

Becker, G. (1981). A Treatise on the Family, MA: Harvard University Press.

Blank, R. (1989), "The Rolle of Part-Time Work in Women's Labor Markel Choices Over Time", American Economic Review, 79 (11) 295-99.

Buddelmeyer, H., Mourre, G. and Ward-Warmedinger, M. (2005), Par-Time Work in EU Countries: Labour Market Mobility, Entry and Exil, ECB working paper series. 
Dekker, R., Muffels, R.J.A. and Stancanelli, E. (2000), "A longitudinal analysis of part-time work by women and men in the Netherlands", in Gustafson, S.S. and Meulders, D. (eds). Gender and the labour market. Econometric evidence of obstacles to achiewing gender equality, New York: MacMillan/St. Martin's Press, $260-87$.

Fouarge, D. (2006), 'Helpt kinderopwang de herintreding van moeders stimuleren?', Tijdschrift woor Arbeidswagsstukken, 22 (3), 268-79.

Fouarge, D. and C. Baajens (2006), Changes of working hours and job mobility: the effect of Dutch legislation, Amsterdam: TLM.Net working paper, see $<W W W$.siswo, uva, $\mathrm{n} / \mathrm{t} / \mathrm{m} / \mathrm{s}, 32$.

Gornick, J., Meyers, M. and Ross, K. (1998), "Public policies and the employment of mothers: a cross-national study' , Social Science Quarterly, 79 (1), 35-54.

Kenjoh, E. (2003), Women's employment around the birth of the first child in Britain, Germany. The Netherlands, Sweden and Japan, ISER working papers, June 200316.

Klammer, U. and Keuzenkamp, S. (2005), Working time options over the life course: Changing Social Security Siructures, European Foundation, Luxembourg: Office for Official Publications of the European Communities.

Muffells, R., Chung, H., Fouarge, D., Klammer, U., Luijkx, R., Manzoni., A., Thiel, A. and Wilthagen, T. (2008), Flexibility and security over the life course, Luxembourg: Office for Official Publications of the European Communities, 52.

O'Reilly, J. and Bothfeld, S. (2002), "What Happens after Working Part Time? Integration " Maintenance or Exclusionary Transitions in Britain and Western Germany". Cambridge Journal of Economics, 26 (4), 409-39.

Román, A., Fouarge, D. and Luijkx, $\mathbb{R} .(2004)$, Career consequences of part-time work: results from Dutch panel data 1990-2001, Tilburg: OSA-rapport A206.

Uunk, W., Kalmijn, M. and Muffells, R. (2005), "The Impact of Young Children on Women's Labour Supply: A Reassessment of Institutional Effects in Europe", Acta sociologica, $48,41-62$.

Van der Lippe, T. (2001), "The effect of individual and institutional constraints on hours of paid work of women: an international comparison', in Van der Lippe, T. and Van Dijk, L. (eds). Women's employment in a comparative perspective. New York: Aldine de Gruyter, 221-43. 